\title{
ANALISA KELAYAKAN BISNIS TERHADAP UMKM GILA CEMILAN DALAM MASA PANDEMI COVID 19
}

\author{
Emliah Hasanah ${ }^{1}$, Deviana Pertiwi ${ }^{2}$, Happy Satrio $^{3}$, Hendra Dwi Prasetya $^{4}$ \\ ${ }^{1-4}$ Fakultas Ekonomi Akuntansi STIE Mahardhika Surabaya \\ emliahhasanah98@gmail.com ${ }^{1}$, Pdeviana300@gmai.com ${ }_{2}^{2}$ \\ happysatrio1993@vamil.com ${ }^{3}$
}

\begin{abstract}
During the Covid 19 pandemic, the condition of the Indonesian nation is currently experiencing a period of crisis, especially in the economic sector, which will cause several social problems, such as termination of employment, the number of unemployed is increasing rapidly and employment opportunities are increasingly narrow. The purpose of this journal is to be responsive to costs incurred during production, to calculate net profit and gross profit, as well as whether or not Keripik Uzuz New Normal and Susu Micuare marketed in Sidoarjo and its surrounding areas. The results showed that the average total cost per month was 3,483,000 resulting from a fixed cost of 263,000, 2,134,500 raw material costs for making intestines and 967,500 micu-making raw materials costs, and 118,000 promotion costs. The "Gila Cemilan 3M" business generates a net profit of approximately 917,000 from revenues of 4,400,000 minus an average total cost of 3,483,000. From the calculation of the total cost, it can be known or not the income, expenses and income earned.
\end{abstract}

Keywords : Business feasibility, production costs, net profit, gross profit

\begin{abstract}
ABSTRAK
Pada saat pandemi Covid 19, kondisi bangsa Indonesia saat ini sedang mengalami masa krisis terutama di bidang ekonomi yang akan menimbulkan beberapa permasalahan sosial, seperti pemutusan hubungan kerja, jumlah pengangguran yang meningkat pesat dan kesempatan kerja yang semakin meningkat. semakin sempit. Tujuan jurnal ini adalah untuk mengetahui biaya-biaya yang timbul selama produksi, menghitung laba bersih dan laba kotor, serta dapat tidaknya Keripik Uzuz New Normal dan Susu Micuare dipasarkan di Sidoarjo dan sekitarnya. Hasil penelitian menunjukkan bahwa total biaya rata-rata per bulan adalah 3.483.000 yang dihasilkan dari biaya tetap sebesar 263.000, 2.134.500 biaya bahan baku pembuatan usus dan 967.500 biaya bahan baku pembuatan miku, serta biaya promosi 118.000. Bisnis "Gila Cemilan 3M" menghasilkan laba bersih sekitar 917.000 dari pendapatan 4.400.000 dikurangi total biaya rata-rata 3.483.000. Dari perhitungan total biaya tersebut dapat diketahui atau tidak pendapatan, biaya dan pendapatan yang diperoleh.
\end{abstract}

Kata Kunci: Kelayakan usaha, biaya produksi, laba bersih, laba kotor

\section{PENDAHULUAN}

Seiring dengan berjalannya waktu, industri-industri di Indonesia semakin menunjukkan ke arah yang positif. Hal ini ditunjukkan dengan banyak berkembangnya industri mulai dari industri skala kecil sampai dengan skala besar. Industri makanan dan minuman merupakan salah satu sektor industri andalan seiring dengan pertumbuhannya yang selalu berada di atas rata-rata. Pertumbuhan ekonomi nasional, perkembangan ekonomi di dunia , membawa dampak terhadap daya beli konsumen. Salah satu perekonomian yang masih berkembang yaitu dalam bidang makanan dan minuman. Oleh karena itu maka suatu perusahaan dituntut untuk selalu mengembangkan inovasi-inovasi dan produk produk terbaru, guna untuk menghadapi persaingan pasar yang cukup ketat. Industri keripik adalah satu industri kuliner yang ada di Indonesia yang cukup diminati para pelaku usaha, karena memiliki cukup banyak konsumen. Keripik merupakan makanan ringan yang berupa irisan tipis yang populer di kalangan masyarakat karena sifatnya yang renyah, 
gurih, tidak terlalu mengenyangkan dan tersedia dalam berbagai rasa seperti asin, pedas, dan manis (Lintang, 2017).

Usaha "Gila Cemilan 3M" baru berdiri di tahun 2020. Proses pembuatannya pun dilakukan oleh anggota kelompok itu sendiri. Sebagian besar dalam pandemi Covid 19 saat ini untuk memasarkan kripik Uzuz Ayam New Normal dan Susu Micu, perlu dilakukan untuk beberapa tahapan dan merancang strategi yang baru agar dapat diterima oleh masyarakat. Pengembangan produk keripik usus ayam dapat dilakukan dengan mencari tahu preferensi atau kesukaan konsumen terhadap produk keripik usus ayam. Preferensi konsumen penting dilakukan, karena dapat membantu pelaku usaha dalam merancang strategi pemasaran yang tepat, guna memenangkan peta persaingan terhadap merek yang beredar di pasaran. Selain itu, preferensi konsumen dapat membantu pelaku usaha dalam menganalisis atribut yang ditawarkan pada produk apakah telah memenuhi keinginan dan harapan konsumen atau belum (Tasmaria, 2017).

Efek dari pandemi saat ini akan membuat khalayak para pengusaha mengalami penurunan omset dan juga akan ber imbas pada pendapatan kripik usus dan micu. Menganalisis tentang kelayakan bisnis, salah satunya dilakukan pada usaha "Gila Cemilan 3M" yang meneliti layak atau tidaknya suatu bisnis yang dijalankan, total biaya yang dibutuhkan selama produksi, menghitung laba kotor dan laba bersih merupakan tujuan dari penelitian ini.

\section{TINJAUAN PUSTAKA}

\section{Pengertian UMKM}

UMKM adalah singkatan dari Usaha Mikro, Kecil, dan Menengah. Sehingga UMKM terdiri dari tiga bentuk usaha berdasarkan skalanya, yaitu meliputi: Usaha
Mikro, Usaha Kecil dan Usaha Menengah. Berikut adalah pengertian dari ketiganya didasarkan Undang-undang.

a. Usaha Mikro adalah usaha produktif milik orang perorangan dan/atau badan usaha perorangan yang memenuhi kriteria usaha mikro sebagaimana diatur dalam undang-undang ini. Kriteria aset: maksimal 50 Juta, kriteria Omzet: Maksimal 300 juta rupiah.

b. Usaha Kecil adalah usaha ekonomi produktif yang berdiri sendiri, yang dilakukan oleh orang perorangan atau badan usaha yang bukan merupakan anak perusahaan atau bukan cabang perusahaan yang dimiliki, dikuasai, atau menjadi bagian baik langsung maupun tidak langsung dari usaha menengah atau usaha besar yang Singgih Muheramtohadi, peran Lembaga Keuangan Syariah dalam Pemberdayaan. Memenuhi kriteria Usaha Kecil sebagaimana dimaksud dalam UndangUndang ini. Kriteria asset: 50 juta - 500 juta, kriteria Omzet: 300 juta - 2,5 Miliar rupiah.

c. Usaha Menengah adalah usaha ekonomi produktif yang berdiri sendiri, yang dilakukan oleh orang perseorangan atau badan usaha yang bukan merupakan anak perusahaan atau cabang perusahaan yang dimiliki, dikuasai, atau menjadi bagian baik langsung maupun tidak langsung dengan usaha kecil atau usaha besar dengan jumlah kekayaan bersih atau hasil penjualan tahunan sebagaimana diatur dalam Undang-Undang ini. Kriteria aset: 500 juta - 10 Miliar, kriteria Omzet: >2,5 Miliar - 50 Miliar rupiah (UU No. 20 Tahun 2008).

Industri UMKM di tanah air saat ini menghadapi situasi yang demikian sulit di tengah perubahan lingkungan bisnis yang 
semakin kompleks. Persainganpun telah menjadi kian ketat seiring dengan derasnya arus perdagangan bebas yang secara otomatis membuat kompetisi dating dari segala penjuru baik domestik, regional, maupun global. (Kartajaya, 2007:1).

Peranan UMKM yang sangat besar tersebut, memberikan penjabaran bahwa UMKM harus dapat ditingkatkan lebih baik lagi. UMKM akan mampu bertahan dan bersaing apabila mampu menerapkan pengelolaan manajemen secara baik. Pengelolaan manajemen secara umum mencakup bidang pemasaran, produksi, sumber daya manusia (SDM), dan keuangan. Konsep dan perancangan tertentu di tingkat strategi merupakan faktor kunci keberhasilan. Analisis mengenai pasar, pelanggan dan produk merupakan suatu hal yang sangat penting dalam dunia yang kompleks. Menurut Purwanto (2008).

\section{Pengertian Keripik Usus Ayam}

Keripik adalah sejenis makanan ringan berupa irisan tipis dari umbi-umbian, buahbuahan atau sayuran yang digoreng di dalam minyak nabati. Selain itu terdapat juga keripik yang terbuat dari dalam tubuh hewan misalkan keripik paru yang di ambil dari tubuh sapi dan keripik usus ayam yang di ambil dari tubuh ayam sehingga menghasilkan produk pangan bermutu tinggi. Untuk menghasilkan rasa gurih dan renyah biasanya dicampur dengan adonan tepung yang di beri taburan rempah tertentu. Secara umum keripik dibuat melalui tahap penggorengan, tetapi ada pula yang hanya melalui penjemuran dan pengeringan. Keripik dapat berasa asin, pedas, asam, gurih atau paduan dari kesemuanya . (Hidayat,2009).

\section{Pengertian Susu Segar}

Susu segar atau susu sapi murni memiliki banyak kandungan gizi. Maharani Hidayat \& Darana (2017) mengatakan bahwa sebagai bahan susu memiliki gizi tinggi yang didalamnya terdapat nutrisi yang dibutuhkan oleh tubuh. Nutrisi tersebut adalah protein, laktosa, lemak, vitamin, mineral dan enzim. Kebutuhan untuk mengonsumsi susu, tidak hanya dianjurkan bagi bayi saja, namun sejak anak-anak sampai dewasa, konsumsi susu sangat dianjurkan untuk dilakukan setiap hari. Kementrian Pertanian (2015) mengungkapkan bahwa konsumsi susu sapi dapat dilakukan dari usia 1-10 tahun sampai usia 20 tahun keatas dengan tingkat konsumsi yang berbeda pada tiap umurnya. Pada usia 1-10 tahun konsumsi susu yang dibutuhkan adalah sekitar $150 \mathrm{ml}$ per hari, sedangkan pada 11-10 tahun konsumsi susu yang dibutuhkan adalah $250 \mathrm{ml}$ per hari dan pada usia 20 tahun keatas konsumsi susu yang dibutuhkan adalah 200 ml per hari (Kementrian Pertanian 2015).

\section{Pengertian Covid 19}

Covid-19 adalah penyakit menular yang diakibatkan infeksi virus corona virus jenis baru. Penyakit ini diketahui muncul pertama kali di Wuhan, Cina pada Desember 2019 (WHO, 2020). Covid-19 merupakan penyakit pernapasan akut yang menjadi pandemik global dan disebabkan oleh novel coronavirus atau SAR-Cov-2 (Erlich, 2020). Covid 19 saat ini telah menjajah negara indonesia, dimana penyebaran penyakit tersebut sangat cepat. Bukan hanya di Indonesia, bahkan di penjuru dunia saat ini sedang mengalami krisis kesehatan. Awalnya penyebaran covid 19 sangat berdampak pada kegiatan ekonomi yang mulai lesu, tidak hanya itu dilansir dari berita harian Kompas (2020) pemerintah di beberapa daerah juga membuat kebijakan penutupan jalan hingga pembatasan wilayah untuk warga yang ingin keluar masuk dalam suatu daerah yang juga disebut lockdown. Namun saat ini dampak dari wabah tersebut juga dirasakan oleh dunia pendidikan. 
Berdasarkan pemahaman para ahli di atas, dapat disimpulkan bahwa studi kelayakan usaha merupakan timbangan awal yang harus dilakukan sebelum menjalankan usaha dan memahami lokasi usaha serta mengendalikan kegiatan operasi untuk memperoleh keuntungan yang sebesarbesarnya.

\section{METODOLOGI PENELITIAN}

Peneliti menggunakan jenis penelitian yang bersifat kuantitatif, sebab Penelitian ini menggunakan jenis penelitian deskriptif kuantitatif, dimana proses penggalian informasi diwujudkan dalam bentuk angka sebagai alat untuk menemukan informasi yang diketahui dan relevan, layak atau tidaknya suatu bisnis pada UMKM yang diterapkan pada Gila Cemilan 3M pada masa pandemi covid 19 saat ini.

\section{Tekhnik Pengumpulan Data}

Teknik pengumpulan data menurut Jhonshon dan Cristensen bahwa metode pengumpulan data merupakan teknik untuk mendapatkan data untuk dianalisi dalam suatu penelitian. Tujuan dari pengumpulan data adalah untuk menemukan data-data yang dibutuhkan dalam proses penelitian. Data tersebut sebagai sumber untuk kemudian dianalisis dan disimpulkan menjadi pengetahuan baru.Dalam penelitian ini menggunakan teknik pengumpulan data observasi participant. Obervasi participant adalah teknik pengumpulan data dengan observasi dimana peneliti terlibat dengan hal yang sedang diamati atau sumber penelitian. Teknik pengumpulan data adalah suatu langkah yang dinilai strategis dalam penelitian, karena mempunyai tujuan yang utama dalam memperoleh data menurut Sugiyono (2016:193). Teknik pengumpulan data merupakan salah satu metode yang ada di dalam pengumpulan data dengan menggunakan teknik atau cara yang digunakan oleh para peneliti untuk mengumpulkan data menurut Riduwan (2010:51). Pengumpulan data dari pandangan mereka berdua adalah suatu prosedur yang cara sistematis dengan cara memperoleh data yang telah dinilai penting menurut Djaman Satori dan Aan Komariah (2011:103)

\section{Rancangan Analisis Data}

Menganalisis biaya produksi, Laba Kotor dan laba Bersih. Untuk mengetahui besarnya pengeluaran, pendapatan, dan laba bersih pada usaha tempe ini dilakukan dengan menggunakan rumus sebagai berikut:

a. Biaya produksi

Biaya produksi adalah semua pengeluaran ekonomis yang harus dikeluarkan untuk memproduksi suatu barang. Berikut rumus untuk menghitung biaya produksi

$$
\begin{aligned}
\mathrm{TC} & =\mathrm{TFC}+\mathrm{TVC} \\
\mathrm{TC} & =\text { Total cost (Biaya Total) } \\
\mathrm{TFC} & =\text { Total Fixed Cost (Biaya Tetap } \\
& \text { Total) }
\end{aligned}
$$

b. Pendapatan

Pendapatan adalah jumlah uang yang diterima oleh pengrajin dalam usaha industri rumah tangga keripik usus. Adapun rumus yang digunakan untuk menghitung pendapatan adalah sebagai berikut.

$\mathrm{TR}=\mathrm{P}$ X Q

$\mathrm{TR}=$ Total Penerimaan

$\mathrm{P}=$ Harga satuan produk

$\mathrm{Q}=$ Quantity (jumlah barang )

c. Keuntungan

Keuntungan usaha merupakan pengurangan pendapatan total dengan biaya total dari usaha home industri keripik usus. Secara matematis dapat ditulis sebagai berikut:

$\pi=\mathrm{TR}-\mathrm{TC}$

$\mathrm{Pd}=$ Pendapatan 
$\mathrm{TR}=$ Total Reveneu (Total Penerimaan)

$\mathrm{TC}=$ Total Cost $($ Total Biaya $)$

\section{Analisis $\mathbf{R} / \mathbf{C}$}

Revenuel Cost Ratio adalah merupakan perbandingan antara total penerimaan dengan total biaya dengan rumusan sebagai berikut. Kelayakan usaha pada usaha tempe didekati dengan menggunakan analisis $\mathrm{R} / \mathrm{C}$ dengan persamaan menurut Soekartawi (2002) sebagai berikut:

$\mathrm{R} / \mathrm{C}=\mathrm{TR} / \mathrm{TC}$

Dimana:

$\mathrm{R} / \mathrm{C}=$ Revenue Cost Rati

$\mathrm{TR}=$ Total Revenue (Total Penerimaan)

$\mathrm{TC}=$ Total Cost $($ Total Biaya)

Dengan Ketentuan:

a. Apabila revenue cost ratio $<1$ maka usaha dinyatakan rugi

b. Apabila revenue cost ratio $=1$ maka usaha dinyatakan impas

c. Apabila revenue cost rasio > 1 maka usaha dinyatakan untung

\section{Waktu dan Tempat Menganalisa}

Dilakukan di daerah Waru, bahwa usaha kripik Uzuz Ayam New Normal dan Susu Micu akan dapat berkembang secara bertahap penelitian ini dilaksanakan melalui beberapa tahap, antara lain:

a. Tahapan persiapan dan perencanaan diantaranya melalui survei produk apa yang akan diputuskan dan dilaksanakan selama 3 bulan.

b. Tahap di lapangan, untuk membeli bahanbahan yang diperlukan dalam usaha.

c. Tahap pengolahan, pemasaran dan pembuatan laporan program kewirausahaan UMKM

\section{HASIL DAN PEMBAHASAN}

Keadan Umum Keripik Uzuz Ayam New Normal dan Susu Micu.

\section{Pengadaan sarana Produksi}

a. Keripik Uzuz Ayam New Normal, pengusaha keripik usus ayam adalah orang yang melakukan suatu kegiatan usaha pengolahan usus ayam untuk menjadikan keripik usus kemudian menjualnya. Perajin keripik Uzuz Ayam New Normal di Jl. Duku Tengah I CA467, Pondok Candra Indah Sidoarjo, dalam penyediaan bahan baku dan sarana produksi dilaksanakan oleh masing masing unit usaha. Usus ayam yang menjadi bahan pokok dalam pembuatan keripik Uzuz Ayam New Normal yang digunakan oleh responden merupakan keripik usus ayam pilihan terbaik yang diperoleh dari distributor usus ayam potong terbaik di Sidoarjo.

b. Susu Micu (Mimik Cucu), perajin Susu Micu adalah orang yang melakukan kegiatan usaha pengolahan susu susu segar untuk menjadikan micu yang kemudian menjualnya. Perajin micu di Jl. Duku Tengah I CA-467, Pondok Candra Indah Sidoarjo, dalam penyediaan bahan baku sarana produksi dilakanakan oleh masing masing usaha. Minuman Susu Micu yang terbuat dari susu segar murni yang kami dapatkan dari peternakan susu sapi perah yang ada di Batu Malang dengan kualitas paling baik.

\section{Proses pembuatan}

a. Proses pembuatan keripik Uzuz Ayam New Normal dimulai dengan cuci bersih usus ayam potong kira kira $5 \mathrm{~cm}$. Diperas saat habis mencuci usus ayamnya atau ditiriskan jangan sampai terlalu banyak air yang terbawa, ulek bawang putih dan ketumbar bersama sedikit saja garam dan penyedap rasa. Lumuri usus yang sudah dicuci dengan bumbu yang sudah di ulek. Ayak semua tepung dan campurkan 
dengan usus yang sudah berbumbu, panaskan minyak di wajan. Bertahap masukan usus kedalam tepung sambal di remas remas sampai tepung menempel. Pisahkan satu satu ususnya, jangan ada yang menggulung atau menempel satu sama lain, karena usus yang menempel atau menggulung atau menggrombol tidak bisa matang sempurna dan tidak bisa kriuk. Ayak dengan saringan usus yang sudah dilumuri tepung sebelum digoreng, agar tepung yang tidak menempel jatuh, karena kalua banyak tepung yang tidak menempel ikut digoreng minyak akan cepat kotor dan menghitam. Setelah minyak panas masukan sekitar 1 senggam usus kewajan. Jangan diaduk-aduk dulu, karena kalau terus diaduk, tepung tidak akan lengket sama sekali saat menggoreng. Tunggu ususnya sedikit mengering, lalu aduk dan goreng hingga matang atau garing. Tunggu dingin terlebih dahulu baru dikemas di standing pouch.

b. Proses pembuatan Susu Micu dimulai dengan masukan susu murni kedalam panci, beri gula dan nyalakan kompor dengan api sedang saja karena susu cepat matang, aduk terus susu murni hingga panas agar susu tidak gosong dan berkerak pada panci, jika susu sudah matang lalu diberikan bubuk perasa minuman. Lalu biarkan susu dingin terlebih dahulu, saring dan masukkan kedalam botol dan diberikan stiker.

\section{Analisis Kelayakan}

a. Analisi Beban

Rata-rata beban tetap, beban variable dan beban keseluruhan saat pembuatan Susu Micudan Kripik Uzuz Ayam New Normal 


\section{Journal MISSY}

\section{(Management and Business Strategy)}

Vol. 1, Nomor. 1 Juni 2020

ISSN : XXXX - XXXX

\begin{tabular}{|c|c|c|c|c|}
\hline No. & Jenis Biaya & Kuantitas & Harga Satuan (Rp) & Jumlah (Rp) \\
\hline 1 & Rata-rata beban tetap & & & \\
\hline 2 & Kompor Gas & 1 Tungku & 147.000 & 147.000 \\
\hline 3 & Regulator + Selang Gas & 1 Unit & 50.000 & 50.000 \\
\hline 4 & Spatula & 1 Unit & 8.000 & 8.000 \\
\hline 5 & Baskom & 2 Unit & 17.000 & 34.000 \\
\hline 6 & Pisau & 2 Unit & 8.000 & 16.000 \\
\hline 7 & Telenan & 1 Unit & 8.000 & 8.000 \\
\hline \multicolumn{4}{|c|}{ TOTAL BEBAN TETAP } & 263.000 \\
\hline 1 & $\begin{array}{l}\text { Rata-rata beban variable Keripik Uzuz Ayam New } \\
\text { Normal }\end{array}$ & & & \\
\hline 2 & Garam & 3 Bungkus & 2.500 & 7.500 \\
\hline 3 & Bawang Putih & $3 \mathrm{~kg}$ & 20.000 & 60.000 \\
\hline 4 & Usus Ayam & $30 \mathrm{~kg}$ & 25.000 & 750.000 \\
\hline 5 & Jeruk Nipis & $3 \mathrm{~kg}$ & 12.000 & 36.000 \\
\hline 6 & Ketumbar & $750 \mathrm{gr}$ & 45.000 & 45.000 \\
\hline 7 & Tepung terigu & $6 \mathrm{~kg}$ & 6.000 & 36.000 \\
\hline 8 & Tepung beras & $3 \mathrm{~kg}$ & 18.000 & 54.000 \\
\hline 9 & Tabung LPG & 9 tabung & 12.000 & 108.000 \\
\hline 10 & Standing Pouch & $300 \mathrm{pcs}$ & 900 & 270.000 \\
\hline 11 & Label Sticker & 120 lembar & 5.000 & 600.000 \\
\hline 12 & Rasa & 12 bungkus & 8.000 & 96.000 \\
\hline 13 & Minyak Goreng @ 2ltr & 3 bungkus & 24.000 & 72.000 \\
\hline \multicolumn{4}{|c|}{ TOTAL BEBAN VARIABEL KERIPIK UZUZ NEW NORMAL } & 2.134.500 \\
\hline 1 & $\begin{array}{l}\text { Rata-rata beban variable } \\
\text { Micuuu (Mimik Cucu) } 5 \text { Varian Rasa }\end{array}$ & & & \\
\hline 2 & Air Galon & 12 Galon & 5.000 & 60.000 \\
\hline 3 & Botol Plastik $280 \mathrm{ml}$ & 200 Botol & 800 & 160.000 \\
\hline 4 & Bubuk Minuman & 5 Rasa & 40.000 & 200.000 \\
\hline 5 & Sticker & 30 lembar & 8.000 & 240.000 \\
\hline 6 & Susu & 18 botol & 15.000 & 270.000 \\
\hline 7 & Gula & $3 \mathrm{~kg}$ & 12.500 & 37.500 \\
\hline \multicolumn{4}{|c|}{ TOTAL BEBAN VARIABEL MICUUU (Mimik Cucu) 5 Varian Rasa } & 967.500 \\
\hline 1 & $\begin{array}{l}\text { Rata-rata beban variable pemasaran, promosi dan biaya } \\
\text { cetak laporan }\end{array}$ & & & \\
\hline 2 & Promosi dan pemasaran & 200 lembar & 125 & 25.000 \\
\hline 3 & Biaya cetak laporan & 60 lembar & 1.500 & 90.000 \\
\hline 4 & Penjilidan & 1 Jilid & 3.000 & 3.000 \\
\hline \multicolumn{4}{|c|}{ TOTAL BEBAN VARIABEL PEMASARAN, PROMOSI DAN BIAYA CETAK LAPORAN } & 118.000 \\
\hline \multicolumn{4}{|c|}{ TOTAL KESELURUHAN } & 3.483.000 \\
\hline
\end{tabular}

b. Rata-Rata pendapatan

Rata-Rata Penjualan Keripik Uzuz

Ayam New Normal dan Susu Micu(Mimik

Cucu)

\begin{tabular}{|c|l|c|}
\hline No. & \multicolumn{1}{|c|}{ Nama Produk } & Jumlah Prod \\
\hline 1. & Keripik Uzuz Ayam New Normal & 300 \\
\hline 2. & Micuuu (Mimik Cucu) & 200 \\
\hline JUMLAH & \multicolumn{2}{l}{} \\
\hline
\end{tabular}

Laba $=$ Total Keseluruhan Penjualan -

Total Keseluruhan Beban Tetap

dan Variabel

$=$ Rp.4.400.000 - Rp.3.483.000

$=$ Rp. 917.000

\section{Analisis Kelayakan Usaha}

$\mathrm{R} / \mathrm{C}$ digunakan mengetahui kelayakan usaha industri keripik Uzuz Ayam New Normal dan micu di Jl. Duku Tengah I CA- 
dikatakan layak. Jika nilai R/C kurang dari 1 bisa dikatakan usaha tersebut tidak layak, jika $\mathrm{R} / \mathrm{C}$ sama dengan 1 bisa dikatakan usaha tersebut tidak mendapatkan untung dan tidak rugi. Adapun metode perhitungan pada usaha keripik Uzuz Ayam New Normal dan micu di Jl. Duku Tengah I CA-467 Pondok Candra Indahwaru sidoarjo adalah sebgai berikut:

$$
\begin{aligned}
& \text { Rata-rata } \mathrm{R} / \mathrm{C}= \\
= & \frac{\text { Total Penerimaan }(T R)}{\text { Total Biaya }(T C)} \\
= & \frac{4.400 .000}{3.483 .000}=1.26
\end{aligned}
$$

Dapat dilihat bahwa usaha keripik Uzuz Ayam New Normal dan micu di Jl. Duku Tengah I CA-467 Pondok Candra Indah Waru Sidoarjo. Rata -rata R/C 1.26. Artinya jika nilai R/C melebihi 1, maka usaha keripik Uzuz Ayam New Normal dan Micu tersebut layak diusahakan dan menguntungkan. Nilai $\mathrm{R} / \mathrm{C}$ sebesar Rp. 1.26 berarti dengan mengeluarkan biaya sebesar 1 satuan maka akan menghasilkan penerimaan sebesar Rp. 1.26 dan pendapatan sebesar Rp. 0,26. Rata rata beban untuk memproduksi keripik Uzuz Ayam New Normal dan Micu di Jl. Duku Tengah I CA-467 Pondok Candra Indah Waru Sidoarjo saat pembuatan keripik Uzuz Ayam New Normal dan Micu dengan bahan baku 30 kilogram adalah sebesar Rp. 3.483.000 yang dihasilkan dari penjumlahan antara biaya tetap sebesar Rp.263.000. dan biaya variable Rp.3.220.000. Dan pendapatan rata-rata yang dihasilkan adalah Rp. 4.400.000 sehingga pendapatan rata rata sebesar Rp.917.000. R/C digunakan mengetahui kelayakan usaha agro industry keripik Uzuz Ayam New Normal dan Susu Micudi Jl. Duku Tengah I CA-467 Pondok Candra Indah Waru Sidoarjo. R/C merupakan keseimbangan pendapatan dan bahan keseluruhan. Cara untuk menentukan layaknya usaha dinilai dari rumus R/C. Jika nilai $\mathrm{R} / \mathrm{C}$ melebih dari 1 maka suatu usaha dikatakan layak. Jika nilai R/C kurang dari 1 bisa dikatan usaha tersebut tidak layak, jika $\mathrm{R} / \mathrm{C}$ sama dengan 1 bisa dikatan usaha tersebut tidak mendapatkan untung dan tidak rugi. Adapun metode perhitungan pada usaha keripik Uzuz Ayam New Normal dan Micu di Jl. Duku Tengah I CA-467 Pondok Candra Indah Waru Sidoarjo adalah sebagai berikut:

Rata-rata $\mathrm{R} / \mathrm{C}=$

$$
\begin{gathered}
=\frac{\text { Total Penerimaan }(T R)}{\text { Total Biaya }(T C)} \\
=\frac{4.400 .000}{3.483 .000}=1.26
\end{gathered}
$$

Dapat dilihat bahwa usaha keripik Uzuz Ayam New Normal dan Micu di Jl. Duku Tengah I CA-467 Pondok Candra Indah Waru Sidoarjo. Rata -rata R/C 1.26 artinya jika nilai R/C melebihi 1, maka usaha keripik Uzuz Ayam New Normal dan Susu Micu tersebut layak diusahakan dan menguntungkan. Nilai R/C sebesar Rp. 1.26 berarti dengan mengeluarkan biaya sebesar 1 satuan maka akan menghasilkan penerimaan sebesar Rp. 1.26 dan pendapatan sebesar Rp. 0,26 . Rata -rata beban untuk memproduksi keripik Uzuz Ayam New Normal dan Susu Micudi Jl. Duku Tengah I CA-467 Pondok Candra Indah Waru Sidoarjo saat pembuatan keripik Uzuz Ayam New Normal dan Susu Micudengan bahan baku 30 kilogram adalah sebesar Rp. 3.483.000 yang dihasilkan dari penjumlahan antara biaya tetap sebesar Rp.263.000. dan biaya variable Rp.3.220.000. Sedangkan rata- rata penerimaan yang dihasilkan sebesar Rp. 4.400.000 sehingga pendapatan rata rata sebesar Rp.917.000.

\section{KESIMPULAN}

Pada Masa Pandemi covid-19 banyak para pengusaha yang melakukan inovasi dan memperbarui varian jenis usahanya. Tidak 
mau kalah dengan para pengusaha lainya. Usaha UMKM Gila cemilan membuka usaha yaitu keripik Uzuz Ayam New Normal dan Susu Micuuuu .Tempat berproduksi Usus ayam dan micu berlokasi di Jl. Duku Tengan I CA 467 Waru Sidoarjo. Penjualan Keripik Usus dan Micu ini setelah dijalankan selam 3 bulan menghasilkan rata -rata R/C 1.26

Analisis yang kami pakai yaitu membandingkan antara pendapatan dengan beban keseluruhan. Rata - rata pendapatan yang dihasilkan sebesar Rp.4.400.000 dikurangi dengan beban produksi,beban variabel, biaya tetap dan tidak tetap sebesar Rp. 3.483.000 sehingga menghasilkan R/C sebesar 1.26 artinya jika nilai R/C melebihi 1 , maka usaha Keripik Uzuz Ayam New Normal dan Susu Micu tersebut layak dijalankan dan diteruskan dalam masa pandemi maupun tidak ada pandemi yang terjadi saat ini.

\section{DAFTAR PUSTAKA}

Lesmana, W Y. 2016. Analisis kelayakan ekonomi pengembangan permanfaatan kima secara berkelanjutan. Bogor. Jurnal mina sains. 2(2):53-62

Gunawan, K. 2019. Peran studi kelayakan bisnis dalam peningkatan UMKM (Studi kasus UMKM di kabupaten kudus). Kudus. Jurnal bisnis dan manajemen islam. 6(2):101-115

Permata Sari I. 2019. Studi kelayakan bisnis usaha mikro kecil menengah (UMKM) pembuatan tahu di desa lubuk sahung kecamatan sukaraja kabupaten seluma ditinjau dari prespektif ekonomi islam. Jurnal doctoral dissertation IAIN Bengkulu.

Muheramtohadi, S. (2017). Peran Lembaga Keuangan Syariah dalam Pemberdayaan UMKM di Indonesia. Muqtasid: Jurnal Ekonomi dan Perbankan Syariah, 8(1), 65-77.
Suci, Y. R. (2017). Perkembangan UMKM (Usaha mikro kecil dan menengah) di Indonesia. Cano Ekonomos, 6(1), 5158.

Setyowati, L., Wulandari, B., \& Ahsana, A. (2019). Meningkatkan Usaha Industri Rumah Tangga Olahan Susu Segar Aneka Rasa Di Kecamatan Purworejo Kota Pasuruan Melalui Program Kemitraan Masyarakat Stimulus. Jurnal VOK@SINDO, 7(2),65-87.

Sari, M. K. (2020). Sosialisasi Tentang Pencegahan Covid-19 di Kalangan Siswa Sekolah Dasar di SD Minggiran 2 Kecamatan Papar. Kediri. Jurnal Karya Abdi Masyarakat, 4(1), 80-83.

Handarini, O. I., \& Wulandari, S. S. (2020). Pembelajaran Daring Sebagai Upaya Study From Home (SFH) Selama Pandemi Covid 19. Jakarta. Jurnal Pendidikan Administrasi Perkantoran (JPAP), 8(3), 496-503.

Pratama B C. 2020. Peningkatan kompetensi usaha mikro kecil dan menengah (UMKM) berbasis Analisa studi kelayakan bisnis. Yogyakarta. Jurnal inovasi dan penerapan Ipteks. 7(2):107-111

Purnamasari D. 2013. Analisis kelayakan bisnis usaha roti ceriwis sebagai oleh oleh khas kota batam. Batam.1(1):8387

Jannah M. 2018.Analisis pengaruh biaya produksi dan tingkat penjualan terhadap laba kotor.Banten. Jurnal ilmiah perbankan Syariah. 4(1):87-112

Arifin N I. 2016. Analisis target costing dalam upaya pengurangan biaya produksi untuk peningkatan laba kotor pada mandala bakery. Jurnal berkala ilmiah efesiensi analisis target.16(3)

Muktiadji N. 2009.Analisis pengaruh biaya produksi dalam peningkatan kemampuaan dalam perusahaan. Jurnal ilmiah kesatuan.11(1) : 1-8 
Andriani D P.2019.Analisis hasil pelatihan perancangan kemasan untuk meningkatkan kualitas pada koperasi dan paguyuban susu segar. Jurnal prosiding seniati. 201-209

Yuli S B. 2013.Kontribusi pendapatan usaha industry kecil keripik usus terhadap pendapatan rumah tangga di desa kanjuruhan. Malang. Jurnal humanity. 7(1)

Sofiah E. 2017. Sistem pendukung keputusan feasibility study untuk menilai kelayakan sebuah bisnis. Jurnal wawasan ilmiah. 8(1)

Sari D \& Husen G N. 2020. Pengaruh pengetahuan pencacatan akuntansi terhadap pertumbuhan ekonomi dengan modal usaha sebagai variable intervening. 5(2) :115-126.

Mulyadi M. 2011. Penelitian kuantiaif dan kualitatif serta pemikiran dasar menggabungkannya. Jakarta. Jurnal studi komunikasi dan media 15(1):128-137.

Nisak K. 2013. Pengaruh pinjaman modal terhadap pendapatan usaha mikro kecil dan menengah. Mojokerto. Jurnal Pendidikan ekonomi. 1(3) 